\title{
Comparison of some biochemical and mineral indices among Norik breed Murán̆ Plain type and Hucul breed mares
}

\author{
Ján Pošivák ${ }^{1}$, Eva Styková ${ }^{1}$, František Novotný ${ }^{1}$, Igor Valocký ${ }^{1}$, Jana Noskovičová1, \\ Marta Tučková2, Ján Bílek ${ }^{3}$, Peter Korim ${ }^{4}$, Terézia Pošiváková ${ }^{5}$ \\ ${ }^{1}$ University of Veterinary Medicine and Pharmacy, Clinic of Horses, ${ }^{2}$ Clinic of Small Animals, ${ }^{3} \mathrm{Clinic}$ of Birds \\ and Exotic Animals, ${ }^{4}$ Department of the Environment, Veterinary Legislation and Economics, \\ Košice, Slovak Republic \\ ${ }^{5}$ University of Prešov, Faculty of Humanities and Natural Sciences, Department of Ecology, \\ Prešov, Slovak Republic
}

Received November 7, 2013

Accepted February 25, 2015

\begin{abstract}
Biochemical analysis in horses is an important aid for determining correct clinical diagnosis of general, infectious, and some parasitic diseases. This work studied the biochemical and mineral indices in mares of two breeds: the Norik breed Murán Plain type and the Hucul breed. A total of 34 mares of the Norik breed Murán̆ Plain type (aged 15.18 \pm 5.99 years) and 28 Hucul mares (aged $9.03 \pm 5.50$ years) were used. Blood serum was analysed using the biochemical analyser Cobas c111 (Roche, Switzerland). Significant difference $(P<0.05)$ was found between the Norik breed Murán̆ Plain type and the Hucul mares in aspartate aminotransferase, alkaline phosphatase, lactate dehydrogenase and gamma-glutamyltransferase activity; significant difference $(P<0.01)$ was found in urea values; and highly significant difference $(P<0.001)$ was found in glucose values. The mineral profile elements showed a highly significant differences $(P<0.001)$ between the Norik breed Murán Plain type and the Hucul mares in phosphorus, magnesium, iron, chloride, potassium, and sodium concentrations. The results confirmed that there are significant differences between horse breeds in some biochemical indices. Therefore, it is appropriate to determine reference values for other horse breeds, as well. To our knowledge, this is the first report that compares biochemical and mineral indices between the Norik breed Murán̆ Plain type and the Hucul breed.
\end{abstract}

Cold-blooded horse, haematological indicators, selected metabolic indicators

The reference values of indices determined in blood may vary according to breed and are affected by age and to a certain extent also by breeding conditions (Bauer et al. 1984, 1985). Appropriate interpretation of the results of the mineral and biochemical profile requires specific reference values for each animal species (Doubek et al. 2003). Differences between thoroughbreds, standardbreds and hot-blooded horses have already been published (Parry 2003). It is now necessary to acquire reference values for different horse breeds.

The Norik breed Murán̆ Plain type is one of the cold-blooded horse breeds mainly intended for work in forestry and agriculture. It is frequently used for hippotherapy and recreational riding for its good character, excellent manoeuvrability, and constitution. In recent history of horses working in forestry the Norik breed Murán Plain type has gained a leading position among other cold-blooded breeds and has steadily shown quality performances in competitions. An important aspect of the Norik breed Murán̆ Plain type is also its contribution to the rural landscape and heritage conservation of Slovakia (Duruttya and Pernica 2000).

The Hucul is a typical small mountain horse coming from the Carpathian Arc and a representative of the autochthonous horse breed in the Carpathian Basin countries. It belongs to the cultural biological heritage of the Carpathian Basin countries. Hucul horses

Address for correspondence:

MVDr. Eva Styková, PhD

Clinic of Horses

University of Veterinary Medicine and Pharmacy

Komenského 73, 041 81, Košice, Slovak Republic

Phone: +421904841647

E-mail: eva_stykova@yahoo.com

http://actavet.vfu.cz/ 
are excellent for horseback riding in the countryside. They are reliable, modest, skilful, tireless, and excel with their calm temperament (Duruttya and Pernica 2000).

There has been a limited number of studies of the biochemical and mineral indices in horses based on the differences between breeds. Therefore, the aim of our work was to determine and compare the differences of biochemical indices of the enzyme, nitrogen, energy and mineral profile between the Norik breed Murán̆ Plain type and the Hucul breed.

\section{Materials and Methods}

Animals and experimental design

The study involved mares of the Norik breed Murán Plain type ( $\mathrm{n}=34$, group A) from the Centre of Horse Breeding Dobšiná, Slovak Republic, and the Hucul breed mares $(n=28$, group B) from 2 farms in the Slovak Republic. The mean ages were $15.18 \pm 5.99$ years for the Norik breed Murán Plain type mares and $9.03 \pm 5.50$ years for the Hucul breed mares. All horses were clinically examined prior to collection of blood samples and were without clinical-pathological symptoms. None of the mares were pregnant or lactating at the time of sampling.

Although the mares were accustomed to handling, they were treated with care to minimize the stress from blood collection. The horses were fed twice a day with hay and oats; no mineral supplement was added to their feed. The mares were grazing on pasture during the day and stabled during the night. Samples were collected in April and May 2011. Blood samples for biochemical examination were taken from the jugular vein in the morning between 7:00 to 10:00 h before feeding. The mares were stabled during the night until 22:00 h. In order to simplify the sampling, values were determined in blood serum. Blood samples were collected using the needles (BD Vacutainer ${ }^{\mathbb{}}$ Precision Glide $^{\mathrm{TM}}$, BD Diagnostics, USA) and test tubes without anticoagulant (Serum-SST ${ }^{\mathrm{TM}}$ II Advance, BD Diagnostics, USA). After blood clotting the samples were centrifuged for $10 \mathrm{~min}$ at $1180 \times \mathrm{g}$. During transport the samples were stored at $8-10{ }^{\circ} \mathrm{C}$ and were analysed within $6 \mathrm{~h}$ after collection due to long transport.

\section{Sample analysis}

Biochemical indices of aspartate aminotransferase - AST $\left(\mu \mathrm{kat} \cdot \mathrm{l}^{-1}\right)$, alanine aminotransferase - ALT $\left(\mu \mathrm{kat} \cdot \mathrm{l}^{-1}\right)$, alkaline phosphatase - ALP $\left(\mu \mathrm{kat}^{-1} \mathrm{l}^{-1}\right)$, lactate dehydrogenase - $\mathrm{LDH}\left(\mu \mathrm{kat} \cdot \mathrm{l}^{-1}\right)$, gamma-glutamyltransferase - GGT $\left(\mu \mathrm{kat} \cdot \mathrm{l}^{-1}\right)$, urea $\left(\mathrm{mmol} \cdot \mathrm{l}^{-1}\right)$, total protein - TP $\left(\mathrm{g} \cdot \mathrm{l}^{-1}\right)$, albumin - ALB $\left(\mathrm{g} \cdot \mathrm{l}^{-1}\right)$, glucose - GLU $\left(\mathrm{mmol} \cdot \mathrm{l}^{-1}\right)$, cholesterol CHOL $\left(\mathrm{mmol} \cdot \mathrm{l}^{-1}\right)$, triglycerides - TG $\left(\mathrm{mmol} \cdot \mathrm{l}^{-1}\right)$, cholesterol - high density lipoprotein - HDL $\left(\mathrm{mmol} \cdot \mathrm{l}^{-1}\right)$, cholesterol - low density lipoprotein - LDL $\left(\mathrm{mmol} \cdot \mathrm{l}^{-1}\right)$, phosphorus - $\mathrm{P}\left(\mathrm{mmol} \cdot \mathrm{l}^{-1}\right)$, calcium - $\mathrm{Ca}\left(\mathrm{mmol} \cdot \mathrm{l}^{-1}\right)$, magnesium $-\mathrm{Mg}$ $\left(\mathrm{mmol} \cdot \mathrm{l}^{-1}\right)$, iron - $\mathrm{Fe}\left(\mu \mathrm{mol} \cdot \mathrm{l}^{-1}\right)$, chloride $-\mathrm{Cl}\left(\mathrm{mmol} \cdot \mathrm{l}^{-1}\right)$, potassium $-\mathrm{K}\left(\mathrm{mmol} \cdot \mathrm{l}^{-1}\right)$ and sodium - $\mathrm{Na}\left(\mathrm{mmol} \cdot \mathrm{l}^{-1}\right)$ were analysed in blood serum in the biochemical analyser Cobas c111 (Roche, Switzerland).

\section{Statistical analysis}

Statistical analysis of the results was done using Student's $t$-test; in case of variance disagreement, Welch's correction was used (Tables 1 and 2). Since a significant difference in age was detected, after the correlation analysis (covariance was determined to a greater extent in the indicators shown in Table 2) analysis of covariance ANCOVA was carried out, but non-significant improvement was determined in the model.

\section{Results}

Analysis of blood samples of 34 mares of the Norik breed Murán Plain type and 28 Hucul breed mares determined individual biochemical indices (Tables 1 and 2).

In the enzymatic profile, significant differences were determined between the breeds in the AST activity $(P<0.05)$, with higher mean activity compared to reference values determined in the Hucul breed $\left(6.41 \pm 1.56 \mu \mathrm{kat}^{-l^{-1}}\right)$; and ALP $(P<0.05)$ with values of $2.67 \pm 0.72 \mu \mathrm{kat}^{\cdot} \mathrm{l}^{-1}$ for the Norik breed Murán Plain type, and $3.26 \pm 1.01 \mu \mathrm{kat} \cdot \mathrm{l}^{-1}$ for the Hucul breed. Alkaline phosphatase activity was higher in the Hucul breed compared to the Norik breed Murán̆ Plain type but non-significant. Significant difference $(P<0.05)$ was determined between the activities of LDH and GGT in the Norik breed Murán Plain type $\left(5.77 \pm 2.41 \mu \mathrm{kat} \cdot \mathrm{l}^{-1}\right.$ and $0.28 \pm 0.07 \mu \mathrm{kat}^{\cdot} \mathrm{l}^{-1}$, respectively) and the Hucul breed $(7.34 \pm 2.15$ $\mu \mathrm{kat} \cdot \mathrm{l}^{-1}$ and $0.50 \pm 0.52 \mu \mathrm{kat}^{\cdot} \mathrm{l}^{-1}$, respectively). Mean LDH activity higher than the reference value was determined in the Hucul breed $\left(7.34 \pm 2.15 \mu \mathrm{kat}^{\cdot{ }^{-1}}\right)$.

Except for urea, which was higher than the reference value in the Hucul breed $(8.96 \pm$ $\left.1.89 \mathrm{mmol}^{-l^{-1}}\right)$ and significantly different $(P<0.01)$, there was no significant difference in 
Table 1. Biochemical indices of the Norik breed Muráň Plain type and the Hucul breed.

\begin{tabular}{|c|c|c|c|c|}
\hline Indices & Norik breed Muráň Plain type & Hucul breed & Significance & Reference values* \\
\hline$\overline{\operatorname{AST}}\left(\mu \mathrm{kat} \cdot \mathrm{l}^{-1}\right)$ & $5.48 \pm 1.05$ & $6.41 \pm 1.56$ & $P<0.05$ & $3.77-5.60$ \\
\hline $\operatorname{ALT}\left(\mu \mathrm{kat} \cdot \mathrm{l}^{-1}\right)$ & $0.17 \pm 0.20$ & $0.18 \pm 0.16$ & & $0.05-0.38$ \\
\hline $\operatorname{ALP}\left(\mu \mathrm{kat} \cdot 1^{-1}\right)$ & $2.67 \pm 0.72$ & $3.26 \pm 1.01$ & $P<0.05$ & $2.30-4.18$ \\
\hline $\mathrm{LDH}\left(\mu \mathrm{kat} \cdot \mathrm{l}^{-1}\right)$ & $5.77 \pm 2.41$ & $7.34 \pm 2.15$ & $P<0.05$ & $2.70-6.87$ \\
\hline $\operatorname{GGT}\left(\mu \mathrm{kat} \cdot \mathrm{l}^{-1}\right)$ & $0.28 \pm 0.07$ & $0.50 \pm 0.52$ & $P<0.05$ & $0.07-0.73$ \\
\hline $\operatorname{UREA}\left(\mathrm{mmol} \cdot \mathrm{l}^{-1}\right)$ & $7.71 \pm 1.48$ & $8.96 \pm 1.89$ & $P<0.01$ & $3.57-8.57$ \\
\hline $\operatorname{TP}\left(g \cdot l^{-1}\right)$ & $66.21 \pm 8.40$ & $65.74 \pm 11.80$ & & $52.0-79.0$ \\
\hline $\operatorname{ALB}\left(g \cdot l^{-1}\right)$ & $30.37 \pm 3.05$ & $30.65 \pm 2.65$ & & $29.0-38.0$ \\
\hline $\operatorname{GLU}\left(\mathrm{mmol}^{-1} \mathrm{l}^{-1}\right)$ & $4.28 \pm 1.05$ & $5.56 \pm 0.82$ & $P<0.01$ & $4.10-6.40$ \\
\hline $\mathrm{CHOL}\left(\mathrm{mmol} \cdot \mathrm{l}^{-1}\right)$ & $2.32 \pm 0.41$ & $2.33 \pm 0.45$ & & $1.94-3.89$ \\
\hline $\mathrm{TG}\left(\mathrm{mmol} \cdot \mathrm{l}^{-1}\right)$ & $0.44 \pm 0.21$ & $0.41 \pm 0.20$ & & $0.25-0.67$ \\
\hline $\operatorname{HDL}\left(\mathrm{mmol}^{-1} \mathrm{l}^{-1}\right)$ & $1.12 \pm 0.51$ & $0.96 \pm 0.60$ & & - \\
\hline $\operatorname{LDL}\left(\mathrm{mmol} \cdot \mathrm{l}^{-1}\right)$ & $0.27 \pm 0.14$ & $0.55 \pm 0.22$ & & - \\
\hline
\end{tabular}

AST - aspartate aminotransferase, ALT - alanine aminotransferase, ALP - alkaline phosphatase, LDH - lactate dehydrogenase, GMT - gamma-glutamyltransferase, TP - total protein, ALB - albumin, GLU - glucose, CHOL - total cholesterol, TG - triglycerides, HDL - cholesterol-high density lipoprotein, LDL cholesterol-low density lipoprotein Data are expressed as arithmetic mean of measures \pm standard deviation

*Reference values for adult hot-blooded horses were kindly obtained from Orsini and Divers (2008).

Table 2. Mineral profile of the Norik breed Murán Plain type and the Hucul breed.

\begin{tabular}{lcccc}
\hline Indices & Norik breed Muráň Plain type & Hucul breed & Significance & Reference values* $^{*}$ \\
\hline $\mathrm{P}\left(\mathrm{mmol} \cdot l^{-1}\right)$ & $0.73 \pm 0.11$ & $1.14 \pm 0.35$ & $P<0.001$ & $0.64-1.82$ \\
$\mathrm{Ca}\left(\mathrm{mmol} \cdot l^{-1}\right)$ & $2.69 \pm 0.19$ & $2.69 \pm 0.34$ & & $2.80-3.40$ \\
$\mathrm{Mg}\left(\mathrm{mmol} \cdot l^{-1}\right)$ & $0.75 \pm 0.08$ & $0.89 \pm 0.08$ & $P<0.001$ & $0.90-1.15$ \\
$\mathrm{Fe}\left(\mu \mathrm{mol} \cdot l^{-1}\right)$ & $19.05 \pm 4.14$ & $33.39 \pm 8.50$ & $P<0.001$ & $13.10-25.10$ \\
$\mathrm{Cl}\left(\mathrm{mmol} \cdot l^{-1}\right)$ & $110.10 \pm 7.23$ & $92.60 \pm 14.17$ & $P<0.001$ & $99.0-109.0$ \\
$\mathrm{~K}\left(\mathrm{mmol} \cdot{ }^{-1}\right)$ & $5.0 \pm 0.59$ & $4.39 \pm 0.74$ & $P<0.001$ & $4.20-5.60$ \\
$\mathrm{Na}\left(\mathrm{mmol} \cdot l^{-1}\right)$ & $146.20 \pm 9.50$ & $122.80 \pm 15.32$ & $P<0.001$ & $137.0-156.0$ \\
age $($ years $)$ & $15.18 \pm 5.99$ & $9.03 \pm 5.50$ & $P<0.001$ & \\
\hline
\end{tabular}

$\mathrm{P}$ - Phosphorus, $\mathrm{Ca}$ - calcium, $\mathrm{Mg}$ - magnesium, $\mathrm{Fe}$ - iron, $\mathrm{Cl}$ - chloride, $\mathrm{K}$ - potassium, $\mathrm{Na}$ - sodium

Data are expressed as arithmetic mean of measures \pm standard deviation

*Reference values for adult hot-blooded horses were kindly obtained from Orsini and Divers (2008).

nitrogen metabolites between the breeds. Concentrations of total protein and albumin were almost the same between breeds.

Indices of cholesterol and triglyceride concentrations did not show significant difference between the breeds. High density lipoprotein concentration was higher in the Norik breed Murán Plain type and LDL concentration was higher in the Hucul breed, but the difference was non-significant. Glucose showed highly significantly lower values $(P<0.001)$ in the Norik breed Murán̆ Plain type breed (Table 1).

In the mineral profile, highly significant differences $(P<0.001)$ were found in $\mathrm{P}, \mathrm{Mg}, \mathrm{Fe}$, $\mathrm{Cl}, \mathrm{K}, \mathrm{Na}$ concentrations between the breeds. Higher than the reference value was the mean Fe concentration $\left(33.39 \pm 8.50 \mathrm{mmol} \cdot \mathrm{l}^{-1}\right)$ in the Hucul breed and the mean Cl concentration $\left(110.1 \pm 7.23 \mathrm{mmol}^{\cdot 1^{-1}}\right)$ in the Norik breed Murán Plain type. Lower than the reference 
value was $\mathrm{Cl}$ concentration $\left(92.60 \pm 14.17 \mathrm{mmol}^{\cdot l^{-1}}\right)$ and $\mathrm{Na}$ concentration $(122.8 \pm 15.32$ $\mathrm{mmol}^{-1} \mathrm{l}^{-1}$ ) in the Hucul breed (Table 2).

\section{Discussion}

Biochemical analysis in horses is important for determining correct clinical diagnosis and optimal treatment according to the severity and overall impact of the disease and the metabolic state in one animal or in the entire herd (Hura et al. 2013).

Reference values may be affected by species, breed, age (Martins et al. 2005), management, breeding conditions (Plotka et al. 1988), stress during blood collection, blood sample storage, different methods used for various analysers and subclinical diseases (Kaneko et al. 1997). The biochemical profile reflects the physiology of each horse breed as well as the horses' training level (Martins et al. 2005). Although the reference range of biochemical indices in horses is fairly broad, physiological variations of certain breeds are usually narrower.

In our study we compared selected biochemical and mineral indices in mares of the Norik breed Murán Plain type and the Hucul breed. We noted that some biochemical indices (ALT, TP, CHOL, and TG) measured in most individual mares of both breeds fell into the physiological range and did not differ significantly between the two breeds. Similarly, no significant differences were found in albumin concentrations between the two breeds, however, slightly lower concentrations of ALB than the minimal reference value were determined in several individuals from both breeds. Lacerda et al. (2006) in their study of thoroughbred racing horses (TB) and Brasileiro de Hipismo jumping horses (BH) also reported no significant differences in concentrations of TP, CHOL, and ALB between these breeds. However, these authors also studied the Criollo horses, which presented higher levels of $\mathrm{CHOL}$ and $\mathrm{TP}$ compared to $\mathrm{TB}$ and $\mathrm{BH}$ horses, which may be related to protein metabolism and diet type.

On the other hand, significantly higher activities of AST, LDH, GGT, and ALP enzymes as well as urea and glucose concentrations were observed in Hucul mares compared to Norik mares. Moreover, concentrations of AST, LDH, GGT, and urea exceeded reference values in several mares, mainly those of the Hucul breed. Significant differences in concentrations of AST, LDH, GGT, urea, and glucose were observed among horses of the TB, BH and Criollo breeds (Lacerda et al. 2006). Similarly, Muñoz et al. (2002) noted different values of LDH, AST and glucose among Andalusian, Arabian, and AngloArabian stallions during exercise. In addition to subclinical diseases and breed differences, the blood profile of horses may be affected by their temperament (thoroughbreds, hotblooded, and cold-blooded horses) (Draper 1999) or age (Martins et al. 2005). The group of Hucul breed horses had a larger number of young animals compared to the Norik breed Murán̆ Plain type horses. The values of muscle enzymes vary during growth and are higher in the younger animals.

Indicators of energy, protein, and mineral metabolism in blood samples as well as assessment of the liver and muscle functions provide orientation in preventive medicine and animal breeding (Muñoz et al. 2010). In this study, differences in the mineral profile between breeds can be caused by different pasture composition, since Norik mares as well as Hucul mares from both farms came from three different localities in Slovakia. Out of the evaluated mineral contents, only calcium concentrations did not present differences between the two breeds. These results are in accordance with the findings of Lacerda et al. (2006) who tested concentrations of calcium, phosphorus, and magnesium in TB, $\mathrm{BH}$ and Criollo horses. In contrast to our results, no interbreed differences were found in plasma chloride, potassium, and sodium concentrations and all values were within normal physiological ranges in Andalusian, Arabian, and Anglo-Arabian horses (Muñoz et al. 
2002). In most Hucul horses, contents of $\mathrm{Na}, \mathrm{Cl}$, and $\mathrm{K}$ were lower than the physiological values which could be related to higher losses caused by e.g. higher physical activity or by their insufficient intake (Meyer and Harvey 2004).

Biochemical indices of the Norik breed Murán Plain type and the Hucul breed show some differences between them, and also in comparison with other horse breeds. The Norik breed Murán Plain type and the Hucul breed are a result of specific breeding and selection and therefore, determination of biochemical indices is specific for each breed.

\section{Acknowledgements}

This work was supported by the Ministry of Education of Slovak Republic VEGA (project no. 1/0366/15) and the basic research of the National Reference Laboratory for Pesticides at the University of Veterinary Medicine and Pharmacy in Košice.

\section{References}

Bauer JE, Harvez JW, Asquith RL, McNully PK, Kivipelto J 1984: Clinical chemistry reference values of foals during the first year of life. Equine Vet J 16: 361-363

Bauer JE, Harvez JW, Asquith RL, McNully PK, Kivipelto J 1985: Serum protein reference values of foals during the first year of life: comparison of chemical and electrophoretic methods. Vet Clin Path 14: 14-22

Doubek J, Bouda J, Doubek M, Fürll M, Knotková Z, Pejřilová S, Pravda D, Scheer P, Svobodová Z, Vodička R 2003: Veterinary Haematology (in Czech). Noviko a.s., Brno, 464 p.

Draper J 1999: Horse Breeds of the World - The Complete Reference to Horse and Pony Breeds. Hermes House, London, $160 \mathrm{p}$

Duruttya M, Pernica O 2000: Horses from Muráň (in Slovak). HIPO-DUR Eva Janzetičová, Košice, 317 p.

Hura V, Novotný F, Boldižár M, Rédl M, Noskovičová J, Horňák S, Petrovič V, Lazar G, Kováč G 2013: Biochemical responses to a non-standard exercise in horses trained for jumping. Acta Vet Brno 82: 161-167

Kaneko JJ, Harvey JW, Bruss ML 1997: Clinical biochemistry of domestic animals, $5^{\text {th }}$ edn. Academic Press, Philadelphia, $932 \mathrm{p}$.

Lacerda L, Campos R, Sperb M, Soares E, Barbosa P, Godinho E, Ferreira R, Santos V, González FD 2006: Hematologic and biochemical parameters in three high performance horse breeds from Southern Brazil. Arch Vet Sci 11: 40-44

Martins C, Orozco CAG, Angelis FHF, Freutas EVV, Chrisovao FG, Queiroz-Neto A, Kacerda Neto JC 2005: Determination of biochemical variables in horses before and after participation in endurance race. Rev Bras Ciênc Vet 12: 62-65

Meyer DJ, Harvey JW 2004: Veterinary laboratory medicine: interpretation and diagnosis, $3^{\text {rd }}$ edn. MO Saunders, St. Louis, $351 \mathrm{p}$.

Muñoz A, Riber C, Santisteban R, Lucas RG, Castejón FM 2002: Effect of training duration and exercise on blood-borne substrates, plasma lactate and enzyme concentrations in Andalusian, Anglo-Arabian and Arabian breeds. Equine Vet J, Suppl 34: 245-251

Muñoz A, Riber C, Trigo P, Castejón F 2010: Hematology and clinical pathology data in chronically starved horses. J Equine Vet Science 10: 581-589

Orsini JA, Divers TJ 2008: Equine Emergencies: Treatment and Procedures. $3^{\text {rd }}$ edn. Saunders Elsevier, Missouri, pp. $755-757$

Parry BW 2003: Normal clinical pathology data. In: Robinson E (Ed.): Current Therapy in Equine Medicine 5. Elsevier, St. Louis, Missouri, pp. 870-886

Plotka ED, Eagle TC, Gaulke SJ, Tester JR, Siniff DB 1988: Hematologic and blood chemical characteristics of feral horses from three management areas. J Wildl Dis 24: 231-239 